\title{
Fossil Mysticeti from the Pleistocene of Santa Maria Island, Azores (Northeast Atlantic Ocean), and the prevalence of fossil cetaceans on oceanic islands
}

\author{
Sérgio P. Ávila, Ricardo Cordeiro, Ana R. Rodrigues, Ana C. Rebelo, Carlos Melo, \\ Patricia Madeira, and Nicholas D. Pyenson
}

\begin{abstract}
Fossil remains of Cetacea are known globally from nearshore marine sediments along continental coastlines, but they are poorly known from volcanic oceanic island archipelagos. Here we report Pleistocene fossil cetacean material from late Neogene and Quaternary age outcrops on the Santa Maria Island of the Azores island archipelago in the North Atlantic Ocean. These remains consist of an isolated and highly worn fragment from the mandible of a medium- to large-sized baleen-bearing mysticete (i.e., Chaeomysticeti), which was exposed at the marine isotope stage 5 (sub-stage MIS 5e) level at Praia do Calhau, after Hurricane Gordon hit Santa Maria Island in August 2012. While this occurrence represents only the second description of Pleistocene cetaceans from volcanic oceanic islands, we predict that fossil cetaceans are likely underreported from oceanic islands, given their extant abundance and richness near oceanic island archipelagos today, whose geomorphology and oceanography provide important settings for the migration and life history patterns of living cetaceans.
\end{abstract}

Sérgio P. Ávila. CIBIO, Centro de Investigação em Biodiversidade e Recursos Genéticos, InBIO Laboratório Associado, Pólo dos Açores, Departamento de Biologia da Universidade dos Açores, Campus de Ponta Delgada, Apartado 1422, 9501-801 Ponta Delgada, Açores, Portugal; and MPB-Marine PalaeoBiogeography group, University of the Azores, Ponta Delgada, Portugal; and Faculdade de Ciências da Universidade do Porto, Rua do Campo Alegre s/n, 4169-007 Porto, Portugal. avila@uac.pt Ricardo Cordeiro. CIBIO, Centro de Investigação em Biodiversidade e Recursos Genéticos, InBIO Laboratório Associado, Pólo dos Açores, Departamento de Biologia da Universidade dos Açores, Campus de Ponta Delgada, Apartado 1422, 9501-801 Ponta Delgada, Açores, Portugal; and MPB-Marine PalaeoBiogeography group, University of the Azores, Ponta Delgada, Portugal. rjpcordeiro@gmail.com Ana R. Rodrigues. Departamento de Biologia da Universidade dos Açores, Campus de Ponta Delgada, Apartado 1422, 9501-801 Ponta Delgada, Açores, Portugal. arprodrigues.17@gmail.com Ana C. Rebelo. CIBIO, Centro de Investigação em Biodiversidade e Recursos Genéticos, InBIO Laboratório Associado, Pólo dos Açores, Departamento de Biologia da Universidade dos Açores, Campus de Ponta Delgada, Apartado 1422, 9501-801 Ponta Delgada, Açores, Portugal; and MPB-Marine PalaeoBiogeography group, University of the Azores, Ponta Delgada, Portugal; and SMNS - Staatliches Museum für Naturkunde Stuttgart, Rosenstein 1, D-70191 Stuttgart, Germany. 
acfurtadorebelo@gmail.com

Carlos Melo. MPB-Marine PalaeoBiogeography group, University of the Azores, Ponta Delgada, Portugal; and Departamento de Geociências da Universidade dos Açores, Campus de Ponta Delgada, 9501-801 Ponta Delgada, Açores, Portugal. casm.azores@gmail.com Patricia Madeira. CIBIO, Centro de Investigação em Biodiversidade e Recursos Genéticos, InBIO Laboratório Associado, Pólo dos Açores, Departamento de Biologia da Universidade dos Açores, Campus de Ponta Delgada, Apartado 1422, 9501-801 Ponta Delgada, Açores, Portugal; and MPB-Marine PalaeoBiogeography group, University of the Azores, Ponta Delgada, Portugal. tamissa@hotmail.com Nicholas D. Pyenson. Department of Paleobiology, National Museum of Natural History, Smithsonian Institution, NHB, MRC 121, PO Box 37012 10th \& Constitution NW Washington, DC 20013-7012, USA. PyensonN@si.edu

Keywords: Fossil Mysticeti; Pleistocene; MIS 5e; oceanic islands; Azores; NE Atlantic

\section{INTRODUCTION}

Extant cetaceans are found in all of the world's oceans, yet their geographic distributions are constrained by resource availability, which are mostly linked to productivity regimes along continental coasts and shelves (Croll et al., 2005; Kaschner et al., 2011). The ecology and distributions of pelagic cetaceans in the open-ocean remain largely unknown because of the logistical challenges of studying and tracking their patterns across ocean basins (Goldbogen et al., 2013). Volcanic oceanic islands provide one means to sample open-ocean cetacean diversity, either as a stable platform for land- or boat-based observations, or via passive monitoring from the stranding record (Pyenson, 2011). In the oceanic island archipelago of the Azores, in the northeast Atlantic Ocean (Figure 1), 28 living cetacean species have been documented in the surrounding waters (Ávila et al., 2011). This area, with narrow shelves and high slopes of the islands (Quartau et al., 2010, 2012, 2014) and, consequently, high depths at a relatively close distance to the shore, is considered as a mating, breeding, and feeding area for sperm whales (Matthews et al., 2001), and as a resting and feeding area for large migratory cetaceans (Silva et al., 2013) due to the abundance of food (Gordon and Steiner, 1992). Large baleen whales, e.g., sei whales Balaenoptera borealis Lesson, 1828, fin whales $B$. physalus (Linnaeus, 1758), Bryde's whale $B$. edeni Anderson, 1878, blue whales B. musculus (Linnaeus, 1758), and North Atlantic right whales Eubalaena glacialis (Müller, 1776) have also been reported from the Azores Islands (Steiner et al., 2007; Olsen et al., 2009; Silva et al., 2012).
In contrast with the moderately high abundance and richness of cetaceans nearby islands in the present-day - e.g., 21 species reported from Galapagos and 16 species reported from the Hawaii island archipelagos in the Pacific Ocean; Palacios et al. (2004), and Maldini et al. (2005), respectively - the fossil record of cetaceans on islands is almost anecdotal in comparison with that of continental shelves (Fitzgerald, 2011). In fact, exceptional cetacean fossil sites with complete, articulated skeletons are mostly reported from localities along former continental shelves, such as the Eocene lagoonal deposits of Wadi Al-Hitan in Egypt (Gingerich, 1992), the Middle Miocene Sharktooth Hill bonebed from California (Pyenson et al., 2009), the Late Miocene site Cerro Ballena of Chile (Pyenson et al., 2014), and from the MioPliocene Pisco Basin of Peru (Muizon, 1988; Esperante et al., 2002, 2008). Neogene outcrops with cetacean remains listed in the Paleobiology Database are also reported from the eastern Atlantic Ocean and of the Mediterranean Sea, including the Miocene of Belgium (Abel, 1905), the Miocene of Portugal (Estevens and Antunes, 2004; Estevens, 2006), and the Pliocene of Spain (Sendra, 1997; Sendra et al., 1998, 1999; Muñiz et al., 2006; Esperante et al., 2009).

Even taking into account that nowadays there are over 20,000 oceanic islands on our planet, to the best of our knowledge, remains of fossil cetaceans have only been reported from the Neogene of Miyako Island (Japan) (Hasegawa and Otsuka, 1973), the Mio-Pliocene of Santa Maria Island (Azores) (Berthois, 1953; Estevens and Ávila, 2007), the Pliocene of the Balearic Islands Menorca (Mercadal et al., 1985) and Maiorca (Mas, 2004) - , and the Pleistocene of Nauru Island (Fitzgerald, 2011), thus attesting the rarity of 
such fossils in volcanic oceanic islands. Fossils of ectoparasitic whale barnacles (Coronula spp.), which are mainly found on living humpback whales Megaptera novaeangliae (Borowski, 1781) were also reported from the Pliocene-Pleistocene of Espiritu Santo Island, Vanuatu Archipelago (Bianucci et al., 2006) and from the Pleistocene of Isabela Island, Galápagos Archipelago (Zullo, 1986), despite the lack of associated cetacean body fossils.

Here we report the second discovery of a Pleistocene cetacean from a volcanic oceanic island, based on a fragmentary mandible from the Pleistocene (the marine isotope stage 5e [MIS 5e], i.e., last interglacial) of Santa Maria Island (Azores).

\section{MATERIALS AND METHODS}

\section{Geographic and Geological Settings}

The Azores archipelago comprises nine volcanic oceanic islands located in the northeast Atlantic Ocean (Figure 1). Santa Maria was the first island to have emerged above sea level during the Late Miocene (Ramalho et al., 2014) and the geological evolution of Santa Maria can be summarised as follows: 1) first subaerial volcanic edifices (Cabrestantes and Porto formations) and building of a subaerial shield volcano during the Late Miocene (Anjos Complex); 2) erosion and probable total submersion and thus, disappearance underwater of the first island of Santa Maria during the Late Miocene-Early Pliocene (Touril Complex); 3) intensification of the volcanic activity and gradual change from submarine to subaerial eruptions, with lava deltas forming along coeval coastlines during the Early Pliocene (Facho-Pico Alto Complex); 4) subaerial and littoral erosion followed by low-volume volcanism associated with monogenetic cones during the Late Pliocene (Feteiras Formation); and 5) uplift and erosion of the edifice from Early Pleistocene to the present (Ávila et al., 2012; Ramalho et al., 2014).

The highly fossiliferous Touril Complex has a total height of $130 \mathrm{~m}$ (Serralheiro, 2003) and was deposited in submarine conditions, during a period when the first island had most probably completely disappeared under water, thus corresponding to a large seamount with shallow depths. These conditions favoured the incorporation in the marine sediments of abundant remains of marine vertebrates including fishes (Zbyszewski and Ferreira, 1962), cetaceans (Estevens and Ávila, 2007), and sharks (Ávila et al., 2012). There are also abundant inver- tebrate species, such as molluscs (Janssen et al., 2008), brachiopods (Kroh et al., 2008), crustaceans (Winkelmann et al., 2010), echinoderms (Madeira et al., 2011), ostracods (Meireles et al., 2012), as well as calcareous algae forming rhodoliths (Rebelo et al., 2014), whose fossils are nowadays exposed in 15 Late Miocene-Early Pliocene outcrops scattered in the island (Ávila et al., in press).

Late Pleistocene deposits are also known from Santa Maria and were recently revised (Ávila et al., 2015). Prainha and Praia do Calhau, both located on the southern shores at about 3-4 m above present sea level (Zbyszewski and Ferreira, 1961; García-Talavera, 1990; Ávila et al., 2002, 2009a, 2009b, 2010), are amongst the best studied outcrops of the island. Ávila et al. (2008) suggested that the Prainha fossiliferous sequence was formed during the MIS $5 \mathrm{e}$, based on U/Th ages on shells of Patella spp., and on faunal, facies, and geomorphological considerations.

\section{Fossil Material}

The primary material for this research was a large fragment of a cetacean mandibular corpus, which was exposed at Praia do Calhau outcrop (3657'07.11'”N, 2506'18.69' W), after Hurricane Gordon hit Santa Maria Island on the evening of August 19 and the night of August 20, 2012. When the specimen was found, only the more poorly preserved end of the fragment was visible.

After obtaining the necessary legal authorization of the "Parque de Ilha de Santa Maria," the skeletal remains were excavated during September 2012 by careful digging with shovels, trowels, knives, and small chisels. The position of the bone was mapped using a grid. Smaller fragments were collected as well and their positions also noted. A stratigraphic section was assembled along a representative vertical profile of the studied MIS 5e outcrop of Praia do Calhau displaying the internal structures and contacts of the sedimentary deposits. All bone fragments were photographed in situ before being removed from the outcrop wrapped in polyurethane foam, to protect them during handling, and subsequently transported to the laboratory, where the material was unpacked and cleaned with brushes, trowels, and small tweezers. No liquids were used during this operation. After cleaning, all bones were again photographed under different orientations. The fossils collected in this study are housed in the "Centro de Interpretação Ambiental Dalberto Pombo," Vila do Porto, Santa Maria Island (Azores, Portugal). 

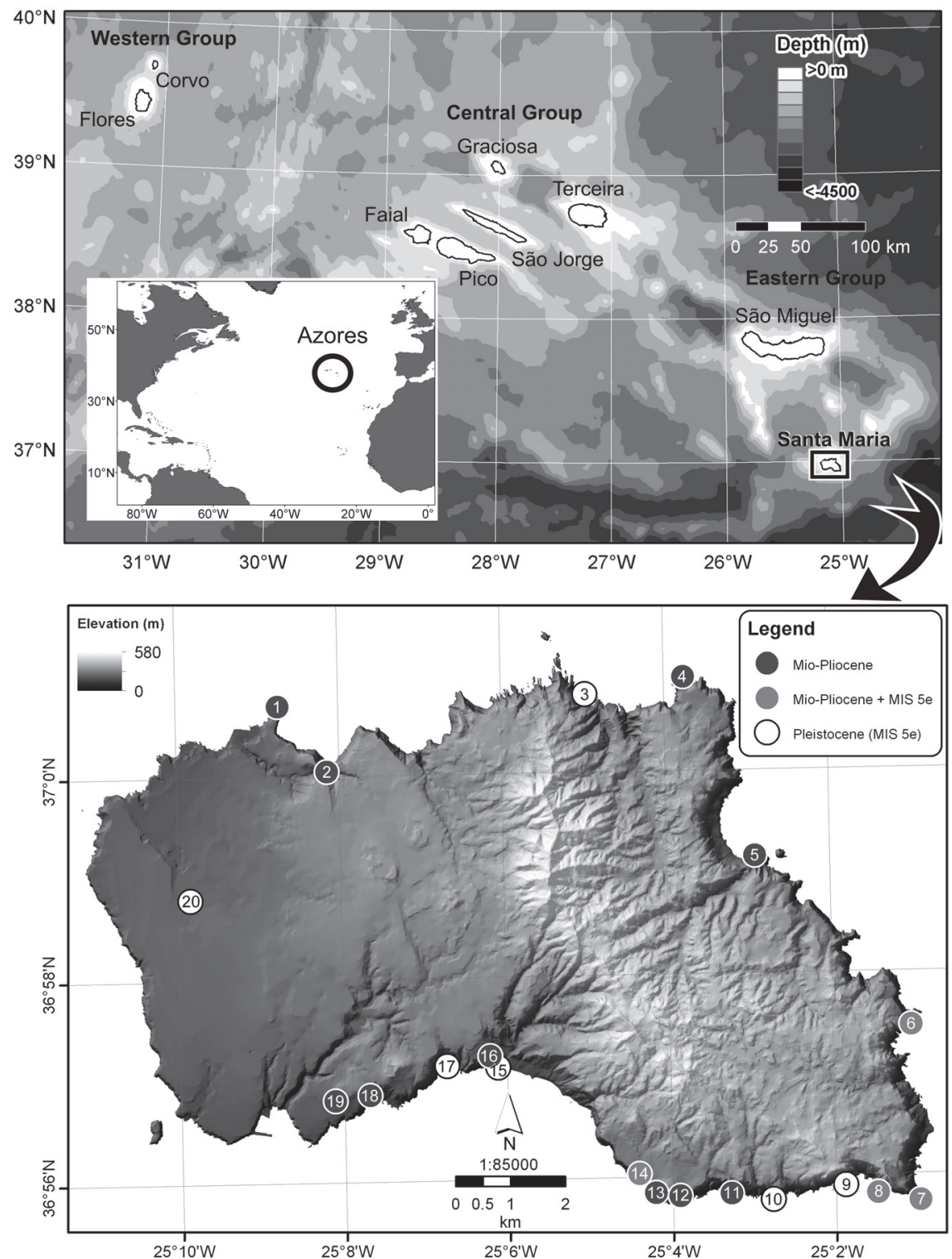

FIGURE 1. Top: location maps. Insert: location of the Azores archipelago in the Northeast Atlantic and location of Santa Maria Island, within the Azores Archipelago. Bottom: map of Santa Maria with the location of the most important Mio-Pliocene and Pleistocene (MIS 5e) outcrops-1, Ponta dos Frades; 2, Cré; 3, Lagoinhas; 4, Ponta do Norte; 5. Ponta Negra; 6, Ponta do Cedro; 7, Ponta do Castelo; 8, Pedra-que-pica; 9, Vinha Velha; 10, Pedrinha da Cré; 11, Baía de Nossa Senhora; 12, Malbusca; 13, West fault of Malbusca; 14, Ichnofossil's cave; 15, Praia do Calhau; 16, Macela; 17, Prainha; 18, Figueiral; 19, Pedreira do Campo; 20, Airport.

Institutional Abbreviations: DBUA-F, fossil collection of the Department of Biology of the University of the Azores.

\section{SYSTEMATIC PALAEONTOLOGY}

Order CETACEA Brisson, 1762 Suborder MYSTICETI Flower, 1864

\section{Infraorder CHAEOMYSTICETI Mitchell, 1989}

Chaeomysticeti incertae sedis

Material examined. DBUA-F 1079 consists of a fragmentary mandibular corpus (Figure 2).

Provenance. The specimen was collected September 17, 2012, at about $0.2 \mathrm{~m}$ above the contact between a basal conglomerate (facies 2, Figure 3 ) and the overlaying $2.6 \mathrm{~m}$ thick, yellowish, partly cross-laminated, volcaniclastic to bioclastic, unce- 


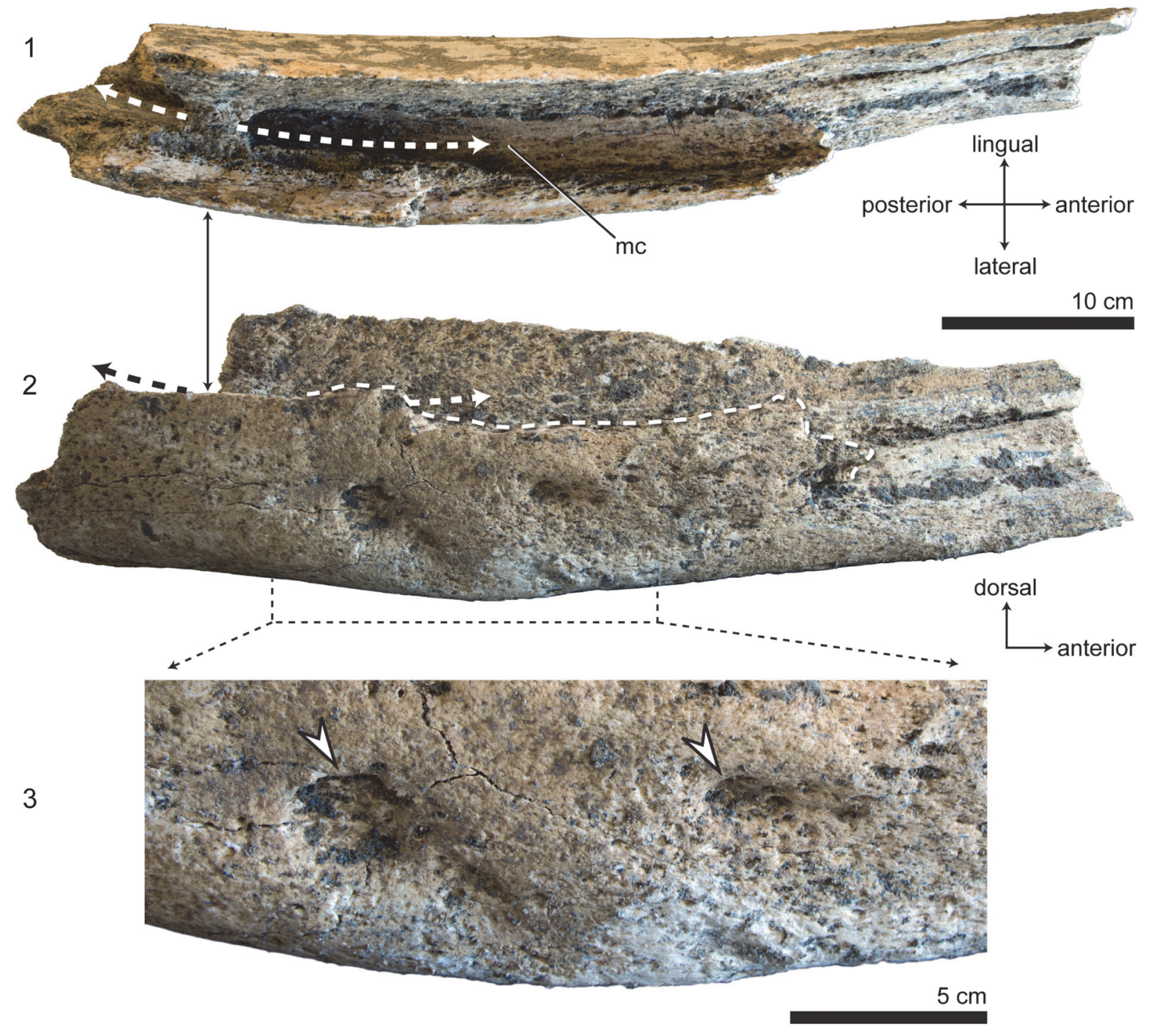

FIGURE 2. Right mandibular corpus (DBUA-F 1079) belonging to a medium-large size Mysticeti. 1, dorsal view; 2, lateral view; and 3, inset magnification of unknown bone modification to the lateral surface (denoted by arrows). Abbreviation " $\mathrm{mc}$ " indicates the mandibular canal. Thick broken arrows show passages of the mandibular canal through the fragment.

mented sands (facies 4, Figure 3 ). These sediments correspond to a beach foreshore (intertidal) facies (Ávila et al., 2015), and they are covered by aeolian dunes and colluvial-alluvial deposits (Figure 3). The specimen was deposited in a northsouth direction, perpendicular to the present shoreline, in a subvertical position, and making a gentle slope of $\sim 23^{\circ}$ with the horizontal.

Description. As preserved, the fragment measures approximately $1.0 \mathrm{~m}$ in greatest length and approximately $0.2 \mathrm{~m}$ in greatest width. It is broadly cylindrical in presentation, dominated by one major surface that is convex and curved along the length of the major axis of the fragment; another surface, opposite of the latter one, is more planar, with a more gentle curve, largely paralleling the direction of the former one (Figure 2). The best-preserved end of the fragment shows how both of these surfaces communicate enclosing a canal that extends similarly parallel to the major axis of the fragment. This inner surface of the bone forming this canal is notably smooth and maintains a consistent diameter $(\sim 3 \mathrm{~cm})$ throughout its length. A small fragment at this best-preserved end, which roofs over this canal, suggests that in life the canal was likely completely enclosed conduit. The more poorly pre- 


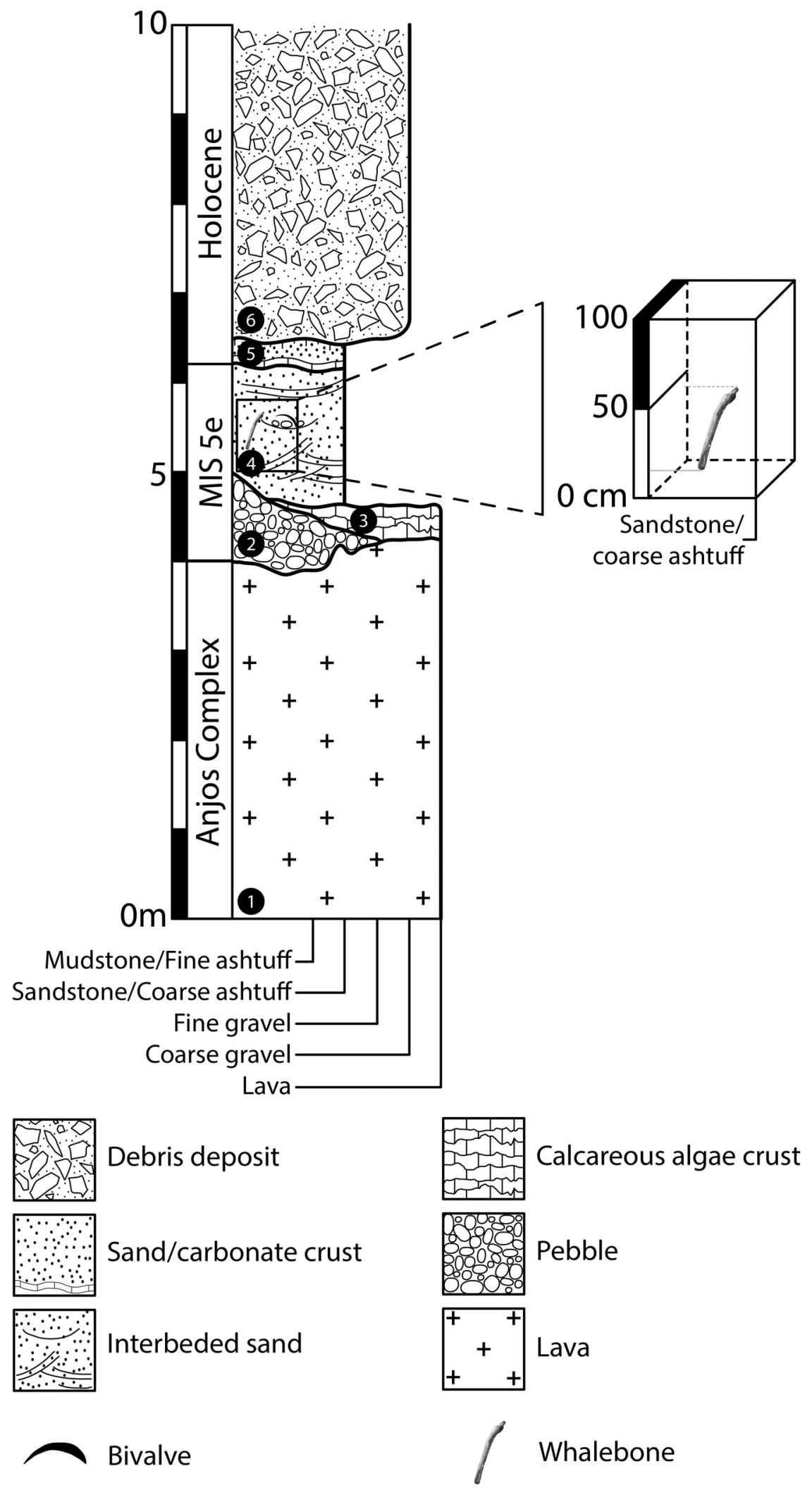

FIGURE 3. Detailed composite stratigraphic column at Praia do Calhau. The numbers depicted in filled circles correspond to facies 1-7, which are described in Ávila et al. (2015). 
served end mostly consists of highly eroded fragments that belong to the planar surface. There are two, small notable pit-like depressions on the convex surface.

Remarks. Although DBUA-F 1079 merely consists of a mandibular corpus, some taxonomic precision can be inferred from its preserved morphology and provenance. First, the general complexity and texture of the preserved cortical bone surface and the exposed cancellous bone indicate that it belongs to Mammalia. Its morphology is inconsistent with rib or any other appendicular or axial postcranial material; moreover, both its consistently sub-cylindrical shape and the inclusion of a large canal preclude it from belonging to the rostrum or another part of the cranium. Its preservation in marine deposits on an oceanic island points strongly to it being a marine mammal; its absolute size $(\sim 1.0 \mathrm{~m}$ in its largest dimension) excludes it belonging to any lineage except for baleen whales (Mysticeti). Thus, on the whole, we argue that DBUA-F 1079 represents a fragment from the mandible of a mysticete.

The mandibular corpus represents a section comprising the approximate mid-length of the element. The maximum width of the fragment is approximately $17 \mathrm{~cm}$; the maximum (and likely sub-complete) dorsoventral height is approximately $18 \mathrm{~cm}$ (Figure 2.1-2). The large canal is thus the mandibular canal, which in life would house the nerves and vasculature that pass anteriorly from the mandibular fossa and exit laterally along mental foramina and, in extant mysticetes, also exit dorsally and anteriorly at relictual alveolar foramina (Pyenson et al., 2012, 2013). Given the overall curvature and orientation of the inferred anatomical planes of the specimen, this fragment appears to represent a right mandible: the more planar surface is medial; and the more convex and curved surface is lateral; the best preserved end thus represents the posterior part of the fragment.

The small depressions on the lateral size of the mandible are too large, diffuse, irregular in shape, and too different in size (with respect to one another) to represent mental foramina, which have a clean, pinched aperture (Figure 2.3). The bone modification in DBUA-F 1079 is unknown among other fossil cetaceans. The overall surface geometry does not match any of the categories of bone modification in marine vertebrate fossils (see Boessenecker and Perry, 2011, table 1), including known patterns generated from bites (e.g., punctures, tooth scrapes) or bioerosion (e.g., boring, bioencrustation). We suspect that they represent some unknown type of bone trauma, parasite or post mortem alteration of the bone surface.

Although DBUA-F 1079 lacks other major morphological features (e.g., coronoid process) that would permit easy and direct identification, based on the general curvature of the mandible, we propose that it does not belong to Eschrichtiidae, which generally exhibits mandibular rami that are straight and not bowed (Noakes et al., 2013); also, the lateral breadth of the fragment is greater than all adult specimens Eschrichtius robustus (Pyenson and Goldbogen, unpublished data). Similarly, we exclude Neobalaenidae because the lateral breadth of the fragment far exceeds that for extant Caperea (which ranges between $3-4 \mathrm{~cm}$, Pyenson and Goldbogen, unpublished data), and there are no extant or fossil Neobalaenidae from the North Atlantic Ocean (Tsai and Fordyce, 2015). Given the size range and remaining taxonomic groups, we cannot discriminate among the latter possibilities: a medium-large species of Balaenopteridae; Balaenidae; or an extinct lineage of Mysticeti, possibly belonging to a very large member of Cetotheriidae sensu lato (Marx, 2011). We thus conservatively argue for its taxonomic identification as a baleen-bearing mysticete (Chaeomysticeti sensu Marx, 2011), likely within the crown of Mysticeti, but cannot exclude it belonging to an unknown stem lineage. Although both Balaenopteridae and Balaenidae have stratigraphic ranges through MIS $5 e$, this latter timeframe is younger that the youngest known fossil Cetotheriidae sensu stricto, a Middle Pleistocene occurrence of Herpetocetus from California (Boessenecker, 2013). It is not clear if large "cetotheriids" in the same body size as midsize Balaenoptera sp., such as Pelocetus (Pyenson and Sponberg, 2011) were alive during the time that this specimen was buried.

\section{DISCUSSION}

Large baleen whales are seasonally reported from the Azores in the course of their annual longdistance migrations between high-latitude summer feeding areas and low-latitude oligotrophic wintering grounds (Silva et al., 2014). Sei, fin, and blue whales are commonly seen in early spring and summer in the waters around the Azores, whereas they are rarely seen in late autumn and winter (Silva et al., 2013); the two latter species are reported to feed in the area surrounding the islands (Visser et al., 2011), namely at the Azores Front and at seamounts, where high phytoplankton and zooplankton biomasses have been reported (Fasham et al., 1985; Huskin et al., 2001; Santos 
et al., 2013). Balaenoptera physalus and B. borealis are the most common baleen whales on the waters surrounding the Azores archipelago. In a study that examined the movements and migratory behavior of these baleen whales, Silva et al. (2013) found evidence that most individuals paused their spring migratory journey and stayed around the Azores for a residence time of up to two months.

Although baleen whale strandings are rare events (López et al., 2002; Pyenson et al., 2014), these phenomena have been reported for the Azores. Gonçalves et al. (1992) reported strandings of a newborn calf of a humpback whale (Megaptera novaeangliae) in São Miguel Island and of an adult sei whale in the same island. Gonçalves et al. (1996) reviewed the cetaceans stranded in the Azores during a period of 5 years (from 1992 to 1996). From a total of 49 strandings, only four $(8.2 \%)$ corresponded to baleen whales: two in São Miguel Island, including a common minke whale (Balaenoptera acutorostrata de Lacépède, 1804) and a sei whale; a fin whale at Terceira Island; and an unidentified whale at Santa Maria Island (Balaenoptera sp.). Necropsis and chemical analyses performed on the carcasses of 12 of the stranded cetaceans concluded natural causes of death (Gonçalves et al., 1996). In March 2013, a $12 \mathrm{~m}$ long fin whale stranding was also reported from Pico Island.

Adverse sea conditions in the Azores are common throughout the year and various authors have reported an increase of strandings during storms (Duguy and Wisdorff, 1988; López et al., 1996). Similar conditions existed in the area of the Azores during the last interglacial, as testified by the presence of this mandible of a baleen whale in the Pleistocene (MIS 5e) fossil record of Santa Maria Island. Numerical model experiments implemented by Kaspar et al. (2007) suggested that the North Atlantic storm track was stronger during MIS 5 e and Ávila et al. (2015) suggested that the occurrence of tropical cyclones during the last interglacial would be expected to be higher than today, thus increasing the possibilities of cetaceans being stranded on the Azores archipelago. Although it is difficult to evaluate whether the fragmentary mandible can be attributed to a stranding event, the taxonomic scope, geographic provenance, and climate conditions around an oceanic island are all consistent with this hypothesis as a potential source for the cetacean material at the MIS 5 e outcrop of Praia do Calhau.

\section{ACKNOWLEDGEMENTS}

We thank the Direcção Regional da Ciência, Tecnologia e Comunicações (Regional Government of the Azores) for financial support and the Clube Naval de Santa Maria and Câmara Municipal de Vila do Porto for field assistance. We are grateful to the organizers and participants of several editions of the International Workshop "Palaeontology in Atlantic Islands" who helped in fieldwork (2005-2014). R. Cordeiro, A.C. Rebelo, and $P$. Madeira benefited, respectively, from grants SFRH/BD/60366/2009, SFRH/BD/77310/2011, and SFRH/BD/61146/2009 by FCT, Portugal. S.P. Ávila acknowledges his Ciência 2008 research contract funded by FCT. S.P. Ávila also acknowledges a SYNTHESYS grant (DE-TAF-1071) to study the palaeontological collections of the Museum für Naturkunde, Berlin. N.D. Pyenson is supported by the Smithsonian Institution and its Remington Kellogg Fund.

\section{REFERENCES}

Abel, O. 1905. Les Odontocètes du Boldérien (Miocène Supérieur) D'Anvers. Mémoires du Musée Royal d'Histoire Naturelle de Belgique, 3:1-155. (In French) Anderson, J. 1878. Anatomical and zoological research; comprising an account of zoological results of two expeditions to western Yunnan in 1868 and 1875. Bernard Quaritch, London.

Ávila, S.P., Amen, R., Azevedo, J.M.N., Cachão, M., and García-Talavera, F. 2002. Checklist of the Pleistocene marine molluscs of Prainha and Lagoinhas (Santa Maria Island, Azores). Açoreana, 9:343-370.

Ávila, S.P., Cachão, M., Ramalho, R., Botelho, A.Z., Madeira, P., Rebelo, A.C., Cordeiro, R., Melo, C., Hipólito, A., Ventura, M.A., and Lipps, J.H. In press. The palaeontological heritage of Santa Maria Island (Azores: NE Atlantic): a revaluation of the geosites in GeoPark Azores and its use in geotourism. Geoheritage.

Ávila, S.P., Madeira, P., Mendes, N., Rebelo, A.C., Medeiros, A., Gomes, C., García-Talavera, F., Silva, C.M. da, Cachão, M., Hillaire-Marcel, C., and Martins, A.M.F. 2008. Mass extinctions in the Azores during the last glaciation: fact or myth? Journal of Biogeography, 35:1123-1129.

Ávila, S.P., Madeira, P., Zazo, C., Kroh, A., Kirby, M., Silva, C.M. da, Cachão, M., and Martins, A.M.F. 2009a. Palaeocology of the Pleistocene (MIS 5.5) outcrops of Santa Maria Island (Azores) in a complex oceanic tectonic setting. Palaeogeography, Palaeoclimatology, Palaeoecology, 274:18-31. 
Ávila, S.P., Medeiros, A., Martins, A.M.F., Silva, A., Melo, C., Gomes, C., Michielsen, G., Madeira, J., Bagaço, L., Silva, L., Fernandes, M., Silva, M., Madeira, P., Cordeiro, R., Meireles, R., and Prieto, R. 2011. Lajes do Pico "À ban-baxe-muro". Editora Publiçor, Ponta Delgada. (In Portuguese)

Ávila, S.P., Melo, C., Silva, L., Ramalho, R., Quartau, R., Hipólito, A., Cordeiro, R., Rebelo, A.C., Madeira, P., Rovere, A., Hearty, P., Henriques, D., Silva, C.M. da, Martins, A.M.F., and Zazo, C. 2015. A review of the MIS $5 \mathrm{e}$ highstand deposits from Santa Maria Island (Azores, NE Atlantic): palaeobiodiversity, palaeoecology and palaeobiogeography. Quaternary Science Reviews, 114:126-148.

Ávila, S.P., Ramalho, R., and Vullo, R. 2012. Systematics, palaeoecology and palaeobiogeography of the Neogene fossil sharks from the Azores (Northeast Atlantic). Annales de Paléontologie, 98:167-189.

Ávila, S.P., Rebelo, A.C., Medeiros, A., Melo, C., Gomes, C., Bagaço, L., Madeira, P., Borges, P.A., Monteiro, P., Cordeiro, R., Meireles, R., and Ramalho, R. 2010. Os fósseis de Santa Maria (Açores). 1. A jazida da Prainha. Observatório Vulcanológico e Geotérmico dos Açores, Lagoa. (in Portuguese)

Ávila, S.P., Silva, C.M. da, Schiebel, R., Cecca, F., Backeljau, T., and Martins, A.M.F. 2009b. How did they get here? Palaeobiogeography of the Pleistocene marine molluscs of the Azores. Bulletin of the Geological Society of France, 180:295-307.

Berthois, L. 1953. Contribution à l'étude lithologique de l'Archipel des Açores. Comunicações dos Serviços Geológicos de Portugal, 34:13-40. (in French)

Bianucci, O., Landini, W., and Buckeridge, J. 2006. Whale barnacles and Neogene cetacean migration routes. New Zealand Journal of Geology \& Geophysics, 49:115-120.

Boessenecker, R.W. 2013. Pleistocene survival of an archaic dwarf baleen whale (Mysticeti: Cetotheriidae). Naturwissenschaften, 100:365-371.

Boessenecker, R.W. and Perry, F.A. 2011. Mammalian bite marks on juvenile fur seal bones from the late Neogene Purisima Formation of Central California. Palaios, 26:115-120.

Borowski, G.H. 1781. Gemeinnüzzige [sic] Naturschichte des Tierreichs. G.L. Lange, Berlin and Stralsund. (In German)

Brisson, M.J. 1762. Regnum animals in classes IX. Distributum, sive synopsis methodical. T. Haak, Leiden. (In Latin)

Croll, D.A., Marinovic, B., Benson, S., Chavez, F.P., Black, N., Ternullo, R., and Tershy, B.R. 2005. From wind to whales: trophic links in a coastal upwelling system. Marine Ecology Progress Series, 289:117-130.

de Lacépède, B.G.E. 1804. Histoire naturelle des cétacées. Histoire naturelle, 37:317. (In French)
Duguy, R. and Wisdorff, D. 1988. Strandings of Cetacea and meteorological data on the Atlantic coast (from the Loire Estuary to Gironde). International Council for the Exploitation of the Sea, CM 1988/N3:1-6.

Esperante, R., Brand, L.R., Chadwick, A., and Poma, O. 2002. Taphonomy of fossil whales in the diatomaceous sediments of the Miocene/Pliocene Pisco Formation, Peru, p. 337-343. In de Renzi, M., Pardo Alonso, M.V., Belinchón, M., Peñalver, E., Montoya, P., and Márquez-Aliaga, A. (eds.), Current Topics on Taphonomy. Ayuntamiento de Valencia, Valencia.

Esperante, R., Brand, L.R., Nick, K.E., Poma, O., and Urbina, M. 2008. Exceptional occurrence of fossil baleen in shallow marine sediments of the Neogene Pisco Formation, Southern Peru. Palaeogeography, Palaeoclimatology, Palaeoecology, 257:344-360.

Esperante, R., Guinea, F.M., and Nick, K.E. 2009. Taphonomy of a Mysticeti whale in the Lower Pliocene Huelva Sands Formation (Southern Spain). Geologica Acta, 7:489-505.

Estevens, M. 2006. Evolução das faunas de mamíferos marinhos do Neogénico de Portugal: correlações paleoambientais e paleobiogeográficas. VII Congresso Nacional de Geologia, 29 June-13 July, Évora (Portugal). (In Portuguese)

Estevens, M. and Antunes, M.T. 2004. Fragmentary remains of odontocetes (Cetacea, Mammalia) from the Miocene of the Lower Tagus Basin (Portugal). Revista Española de Paleontología, 19:93-108.

Estevens, M. and Ávila, S.P. 2007. Fossil whales from the Azores. Açoreana, Supplement 5:140-161.

Fasham, M.J.R., Platt, T., Irwin, B., and Jones, K. 1985. Factors affecting the spatial pattern of the deep chlorophyll maximum in the region of the Azores Front. Progress in Oceanography, 14:129-165.

Fitzgerald, E.M.G. 2011. A fossil sperm whale (Cetacea, Physeteroidea) from the Pleistocene of Nauru, Equatorial Southwest Pacific. Journal of Vertebrate Paleontology, 31:929-931.

Flower, W.H. 1864. Notes on the skeletons of whales in the principal museums of Holland and Belgium, with description of two species apparently new to science. Proceedings of the Zoological Society of London, 1:384-420.

García-Talavera, F. 1990. Fauna tropical en el Neotirreniense de Santa Maria (I. Azores). Lavori Societá Italina di Malacologia, 23:439-443. (In Spanish with English abstract)

Gingerich, P.D. 1992. Marine mammals (Cetacea and Sirenia) from the Eocene of Gebel Mokattam and Fayum, Egypt: Stratigraphy, age, and paleoenvironments. University of Michigan Papers on Paleontology, 30:1-84.

Goldbogen, J.A., Friedlaender, A.S., Calambodkis, J., McKenna, M.F., Simon, M., and Nowacek, D.P. 2013. Integrative approaches to the study of baleen whale diving behavior, feeding performance, and foraging ecology. BioScience, 63:90-100. 
Gonçalves, J.M., Barreiros, J.P., Azevedo, J.M.N., and Norberto, R. 1996. Cetaceans stranded in the Azores during 1992-1996. Arquipélago, 14A:57-65.

Gonçalves, J.M., Galhardo, L., and Brum, J. 1992. Marine mammals stranded in the Azores during 1990-91. Arquipélago, 10:113-118.

Gordon, J. and Steiner, L. 1992. Ventilation and dive patterns in sperm whales, Physeter macrocephalus, in the Azores. Report of the International Whaling Commission, 42:561-565.

Hasegawa, Y. and Otsuka, H. 1973. Fossil vertebrates from the Miyako Island. Memoirs of the National Science Museum, 6:39-52.

Huskin, I., Anadón, R., Medina, G., Head, R.N., and Harris, R.P. 2001. Mesozooplankton distribution and copepod grazing in the Subtropical Atlantic near the Azores: influence of mesoscale structures. Journal of Plankton Research, 23:671-691.

Janssen, A.W., Kroh, A., and Ávila, S.P. 2008. Early Pliocene heteropods and pteropods (Mollusca, Gastropoda) from Santa Maria (Azores, Portugal): systematics and biostratigraphic implications. Acta Geologica Polonica, 58:355-369.

Kaschner, K., Tittensor, D.P., Ready, J., Gerrodette, T., and Worm, B. 2011. Current and future patterns of global marine mammal biodiversity. PLOS ONE, 6:e19653.

Kaspar, F., Spangehl, T., and Cubasch, U. 2007. Northern hemisphere winter storm tracks of the Eemian interglacial and the last glacial inception. Climate of the Past, 3:181-192.

Kroh, A., Bitner, M.A., and Ávila, S.P. 2008. Novocrania turbinata (Brachiopoda) from the Early Pliocene of the Azores (Portugal). Acta Geologica Polonica, 58:473-478.

Lesson, W.H. 1828. Compléments des oeuvres de Buffon ou Histoire naturelle des animaux rares découverts par les naturalistes et les voyageurs depuis la mort de Buffon. Chez Baudouin Frères, Éditeurs, Paris. (In French)

Linnaeus, C. 1758. Systema Naturae per regna tria naturae, secundum classes, ordines, genera, species, cum characteribus, differentiis, synonymis, locis. Laurentius Salvius, Holmiae. (In Latin)

López, A., Cendrero, O., Pérez, C., and Castrillo, G.G. 1996. Marine mammals stranded on the North and Northwest Spain in 1995. International Council for the Exploitation of the Sea, CM 1996/N, 9:1-3.

López, A., Santos, M.B., Pierce, G.J., González, A.F., Valeiras, X., and Guerra, A. 2002. Trends in strandings and by-catch of marine mammals in northwest Spain during the 1990s. Journal of the Marine Biological Association of the United Kingdom, 82:513-521.

Madeira, P., Kroh, A., Cordeiro, R., Meireles, R., and Ávila, S.P. 2011. The fossil echinoids of Santa Maria Island, Azores (Northern Atlantic Ocean). Acta Geologica Polonica, 61:243-264.
Maldini, D., Mazzuca, L., and Atkinson, S. 2005. Odontocete stranding patterns in the main Hawaiian Islands (1937-2002): how do they compare with live animal surveys? Pacific Science, 59:55-67.

Matthews, J.N., Steiner, L., and Gordon, J. 2001. Markrecapture analysis of sperm whale (Physeter macrocephalus) photo-id data from the Azores (19871995). Journal of Cetacean Research and Management, 3:219-226.

Marx, F.G. 2011. The more the merrier? A large cladistic analysis of mysticetes, and comments on the transition from teeth to baleen. Journal of Mammalian Evolution, 18:77-100.

Mas, G. 2004. Comunicació preliminar sobre la freqüència de grans Cetacis (Mammalia) al Pliocè mitjà superior de la conca sedimentària de Palma (Illes Balears). Implicacions paleoambientals, p. 63-67. In Pons, G.X. (ed.), IV Jornades de Medi Ambient de les Illes Balears. Ponències $i$ Resums. Societat d'Història Natural de les Balears. (In Spanish)

Meireles, R.P., Faranda, C., Gliozzi, E., Pimentel, A., Zanon, V., and Ávila, S.P. 2012. Late Miocene marine ostracods from Santa Maria Island, Azores (NE Atlantic): Systematics, palaeoecology and palaeobiogeography. Révue de Micropaléontologie, 55:133-148.

Mercadal, B., Pilleri, G., and Casinos, A. 1985. A tooth of Scaldicetus grandis (Du Bus, 1872) (Physeteridae) from Aire Island (Menorca, Spain). Investigations on Cetacea, 17:31-34.

Mitchell, E.D. 1989. A new cetacean from the Late Eocene La Meseta Formation Seymour Island, Antarctic Peninsula. Canadian Journal of Fisheries and Aquatic Sciences, 46:2219-2235.

Muizon, C. 1988. Les vertebres fossiles de la Formation Pisco (Perou). Troisieme partie: Les Odontocetes (Cetacea, Mammalia) du Miocene. Editions Recherche sur les Civilisations, Paris. (In French)

Müller, O.F. 1776. Zoologiae Danicae Prodromus seu Animalium Daniae et Norvegiae indigenarum characteres, nomina, et synonyma imprimis popularium. Hafniae, Typiis Hallageriis. (In Latin)

Muñiz, F., Haro, J., Castilla, E., López, M.A., Quintero, M.C., Martín, M., Jesús, P., Martos, C., and Toscano, A. 2006. Intervenciones paleontológicas sobre restos de cetáceos misticetos del Plioceno de la provincia de Huelva, SO de España, p. 2043-2066. In Junta de Andalucia, Consejería de Cultura (ed.), Anuario Arqueológico de Andalucía. Consejería de Cultura, Junta de Andalucia, Andalucia. (In Spanish)

Noakes, S.E., Pyenson, N.D., and McFall, G. 2013. Late Pleistocene gray whales (Eschrichtius robustus) offshore Georgia, U.S.A., and the antiquity of gray whale migration in the North Atlantic Ocean. Palaeogeography, Palaeoclimatology, Palaeoecology, 392:502-509. 
Olsen, E., Budgell, P., Head, E., Kleivane, L., Nøttestad, L., Prieto, R., Silva, M.A., Skov, H., Víkingsson, G.A., Waring, G., and Øien, N. 2009. First satellite-tracked long-distance movement of a sei whale (Balaenoptera borealis) in the North Atlantic. Aquatic Mammals, 35:313-318.

Palacios, D.M., Salazar, S.K., and Day, D. 2004. Cetacean remains and strandings in the Galapagos Islands, 1923-2003. Latin American Journal of Aquatic Mammals, 3:127-150.

Pyenson, N.D. 2011. The high fidelity of the cetacean stranding record: insights into measuring diversity by integrating taphonomy and macroecology. Proceedings of the Royal Society B: Biological Sciences, 278:3608-3616.

Pyenson, N.D., Goldbogen, J.A., and Shadwick, R.E. 2013. Mandible allometry in extant and fossil Balaenopteridae (Cetacea: Mammalia): the largest vertebrate skeletal element and its role in rorqual lungefeeding. Biological Journal of the Linnean Society, 108:586-599.

Pyenson, N.D., Goldbogen, J.A., Vogl, A.W., Szathmary, G., Drake, R.L., and Shadwick, R.E. 2012. Discovery of a sensory organ that coordinates lunge-feeding in rorqual whales. Nature, 485:498-501.

Pyenson, N.D., Gutstein, C.S., Parham, J.F., Le Roux, J.P., Chavarría, C.C., Little, H., Metallo, A., Rossi, V., Valenzuela-Toro, A.M., Velez-Juarbe, J., Santelli, C.M., Rogers, D.R., Cozzuol, M.A., and Suárez, M.E. 2014. Repeated mass strandings of Miocene marine mammals from Atacama Region of Chile point to sudden death at sea. Proceedings of the Royal Society B: Biological Sciences, 281:20133316.

Pyenson, N.D., Irmis, R.B., Barnes, L.G., Mitchell, Jr. E.D., McLeod, S.A., and Lipps, J.H. 2009. Origin of a widespread marine bonebed deposited during the middle Miocene Climatic Optimum. Geology, 37:519-522.

Pyenson, N.D. and Sponberg, S.N. 2011. Reconstructing body size in extinct crown Cetacea (Neoceti) using allometry, phylogenetic methods and tests from the fossil record. Journal of Mammalian Evolution, 18:269-288.

Quartau, R., Hipólito, A., Romagnoli, C., Casalbore, D., Madeira, J., Tempera, F., Roque, C., and Chiocci, F.L. 2014. The morphology of insular shelves as a key for understanding the geological evolution of volcanic islands: Insights from Terceira Island (Azores). Geochemistry Geophysics Geosystems, 15:1801-1826.

Quartau, R., Tempera, F., Mitchell, N.C., Pinheiro, L.M., Duarte, H., Brito, P.O., Bates, C.R., and Monteiro, J.H. 2012. Morphology of the Faial Island shelf (Azores): the interplay between volcanic, erosional, depositional, tectonic and mass-wasting processes. Geochemistry, Geophysics, Geosystems, 13:1-30.
Quartau, R., Trenhaile, A.S., Mitchell, N.C., and Tempera, F. 2010. Development of volcanic insular shelves: Insights from observations and modelling of Faial Island in the Azores Archipelago. Marine Geology, 275:66-83.

Ramalho, R.S., Helffrich, G., Madeira, J., Cosca, M., Quartau, R., Thomas, C., Hipólito, A., and Ávila, S.P. 2014. The emergence and evolution of Santa Maria Island (Azores) - the conundrum of uplifting islands revisited. AGU Fall Meeting, 15-19 December, San Francisco (USA).

Rebelo, A.C., Rasser, M.W., Riosmena-Rodríguez, R., Neto, A.I., and Ávila, S.P. 2014. Rhodolith forming coralline algae in the Upper Miocene of Santa Maria Island (Azores, NE Atlantic): a critical evaluation. Phytotaxa, 190:370-382.

Santos, M., Moita, M.T., Bashmachnikov, I., Menezes, G.M., Carmo, V., Loureiro, C.M., Mendonça, A., Silva, A.F., and Martins, A. 2013. Phytoplankton variability and oceanographic conditions at Condor seamount, Azores (NE Atlantic). Deep-Sea Research II, 98:52-62.

Sendra, J. 1997. Los yacimientos de mamíferos marinos del Neógeno del Sur de la provincia de Alicante, p. 237-240. In Grandal, A., Gutiérrez-Marco, P., and Santos, L. (eds.), XIII Jornadas de Paleontología. La Coruña (Spain). Sociedad Española de Paleontología, Madrid. (In Spanish)

Sendra, J., Muñiz, F., and Mayoral, E. 1999. Primeros datos sobre misticetos (Mammalia, Cetacea, Balaenopteridae) en el Plioceno inferior de la Cuenca del Guadalquivir (Lepe, Huelva). Temas Geológico y Mineros, 26:356-361. (In Spanish with English abstract)

Sendra, J., Stokes, M., and Oltra, V. 1998. Excavación de un misticeto (Mammalia, Cetacea) en el Plioceno del sector norte de la Cuenca Vera (Almería), p. 177-180. In Sociedad Española de Paleontología (ed.), XIV Jornadas de Paleontología, Tenerife (Spain). Sociedad Española de Paleontología, Madrid. (In Spanish)

Serralheiro, A. 2003. A geologia da ilha de Santa Maria, Açores. Açoreana, 10:141-192. (In Portuguese)

Silva, M.A., Prieto, R., Cascão, I., Seabra, M.I., Machete, M., Baumgartner, M.F., and Santos, R.S. 2014. Spatial and temporal distribution of cetaceans in the midAtlantic waters around the Azores. Marine Biology Research, 10:123-137.

Silva, M.A., Prieto, R., Jonsen, I., and Santos, R.S. 2013. North Atlantic blue and fin whales suspend their spring migration to forage in middle latitudes: building up energy reserves for the journey? PLoS ONE, 8:e76507.

Silva, M.A., Steiner, L., Cascão, I., Cruz, M.J., Prieto, R., Cole, T., Hamilton, P.K., and Baumgartner, M.F. 2012. Winter sighting of a known western North Atlantic right whale in the Azores. Journal of Cetacean Research and Management, 12:65-69. 
Steiner, L., Silva, M.A., Zereba, J., and Leal, M.J. 2007. Bryde's Whales, Balaenoptera edeni, observed in the Azores: a new species record for the region. Marine Biodiversity Records, 1:1-6.

Tsai, C.-H. and Fordyce, R.E. 2015. Ancestor-descendant relationships in evolution: origin of the extant pygmy right whale, Caperea marginata. Biology Letters, 11:20140875.

Visser, F., Hartman, K.L., Pierce, G.J., Valavanis, V.D., and Huisman, J. 2011. Timing of migratory baleen whales at the Azores in relation to the North Atlantic spring bloom. Marine Ecology Progress Series, 440:267-279.
Winkelmann, K., Buckeridge, J.S., Costa, A.C., Dionísio, M.A.M., Medeiros, A., Cachão, M., and Ávila, S.P. 2010. Zullobalanus santamariaensis sp. nov. a new late Miocene barnacle species of the family Archeobalanidae (Cirripedia: Thoracica), from the Azores. Zootaxa, 2680:33-44.

Zbyszewski, G. and Ferreira, O. da V. 1961. La faune marine des basses plages quaternaires de Praia et Prainha dans l'ile de Santa Maria (Açores). Comunicações dos Serviços Geológicos de Portugal, 45:467-478. (In French)

Zbyszewski, G., and Ferreira, O. da V. 1962. La faune Miocène de l'île de Santa Maria (Açores). Comunicações dos Serviços Geológicos de Portugal, 46:247-289. (In French)

Zullo, V.A. 1986. Quaternary barnacles from the Galápagos Islands. Proceedings of the California Academy of Sciences, 44:55-66. 